\title{
Influence of sodium alginate on the formation of the structure of the products from chopped and minced meat
}

\author{
Anna Vasyukova $^{1 *}$, Marina Kononenko ${ }^{1}$, Alexander Moshkin ${ }^{1}$, Maxim Vasyukov $^{1}$, Anatoly Kushnarenko ${ }^{1}$ and Olga \\ Binkovskaya $^{2}$ \\ ${ }^{1}$ K.G. Razumovsky Moscow State University of Technologies and Management (the First Cossack University), 1090004 Moscow, \\ Russia \\ ${ }^{2}$ Belgorod State National Research University, P Sciences, Food Technology Department, 308015 Belgorod, Russia
}

\begin{abstract}
The paper presents the results of using algae as a natural additive to chopped semi-finished meat products. The optimal ratio is set by means of the design method and the results of organoleptic assessment. The mathematical models that help to determine the optimal values of the factors and $\mathrm{C}, \mathrm{W}$ and $\mathrm{T}$ (concentration of the components, moisture content and duration of mincing) are obtained.
\end{abstract}

\section{Introduction}

Nowadays the growth of the market of products, enriched with amino acids, vitamins, mineral and pectin substances, food fibers, is fixed in Russia.

The development of the products of new generation that meet the requirements of the healthy nutrition, is the main objective in the food industry and the food service. Hippocrates, at his time, stated about the importance of healthy nutrition for disease prevention [1]. The restructuring of the nutrition of the Russian people aimed at providing the sufficient amount of protein is one of the main tasks promoting the optimization of the program on healthy nutrition and longevity of the population. To transfer to the use of the intense methods in the modern food technology, at present time non-traditional protein raw materials, food fibers and polysaccharides for functional food products are used $[3,5]$.

The level of protein shortage in food products of animal origin contribute to the study of the scientific works concerning the development of the technology of new kinds of meat products that contain both meat and plant protein-rich components $[1,5,6]$.

Seaweeds (Laminaria and Fucus) have been the only industrial source of alginate, widely used in the food industry and other spheres. Emulsifying properties of alginates specify their usage in the production of dairy products. The addition of the alginates to the dairy products increases their stability and expiration date. The use of alginate in the production of ice-cream has increased, as it makes the product with soft consistency and even texture, it minimizes the process of crystallization and efficiently extends the expiration date $[5,7,8]$.
The main providers of the essential amino acids are proteins of meat, fish, eggs, milk and beans $[1,4]$. To get the nutritional proteins from the plant raw materials is the fastest and efficient way in the production of the mixed meat products with unlimited potential properties, which can compensate the scarcity of animal proteins, polysaccharides and a number of mineral substances $[1$, 4, 9-11].

Therefore, the technology of combining the animal and plant components is considered to be promising in the development of the food industry [12].

The analysis of the literary data shows that the use of Laminaria and Fucus, containing the alginate substances, is steadily developing $[13,14]$. Alginate is added to yogurt that improves and keeps its structure and consistency. In this case polysaccharide can be added into the milk during its preparation or after milk coagulation. Alginates are widely used as additives that bind water, prevent from weeping of protein compounds and contribute to getting minced meat (fish or meat) of certain consistency [13-18]. To prevent raw minced fish meat from weeping while thawing the concentration of alginates do not exceed $0.1-0.5 \%$, as a rule $[5,19]$.

While preparing paste-like fish products, minced fish is subjected to double thermal processing. First, in order to prevent component separation and weeping, minced meat is subjected to thermal processing, and then flavor additives are added. The obtained product is homogenized, packed and sterilized for the second time, due to this its biological value is decreased. The concentration of alginate in the products received can be $0.5-2.0 \%$ depending on the product consistency $[5,15]$.

Alginates are useful as additives, they improve waterretaining ability, elasticity and stability when minced fish and meat are stored and processed thermally. One of the

\footnotetext{
* Corresponding author: vasyukova-at@yandex.ru
} 
main tasks the researchers face while developing food and therapeutic products, is to give them a specific form and structure during the process of production. Getting the stable systems with desired composition and properties is a complex task, that is why alongside the formation, granulation and pelletization it is recommended to use stabilizers - substances that change the product consistency $[5,16,17]$.

The significance of the research is to examine the development of new meat products using algae as a plant additive.

The aim of the paper is to study the use of algae in the formulas of chopped and minced meat products

\section{Experimental}

To achieve the set goals other formulas in the given sphere have been analyzed, in order to determine the optimal ratio of the plant additives while setting the experiment.

According to the methods developed for making the experiments in the laboratory of MSUTM named after K.G. Razumovsky, there has been made an experimental manufacture of chopped semi-finished products using the raw materials such as minced meat (beef, pork, mutton, chicken and duck), algae (laminarium), salt, spices and onion.

The formulas of meat products from chopped and minced meat have been developed with the help of the scheduling method [20, 21].

As soon as the formation of semi-finished products with different variations of paste-like concentrates of algae and meat was finished, the trade analysis was made; according to its results the samples, claimed as the best ones, were subjected to further tests in terms of storage and expiration date of the product. At the certain stages of storage of the samples such parameters as microbiological, physical and chemical and organoleptic were studied according to SanPiN 2.3.2.1078-01.

\section{Result and discussion}

To determine the option of using algae in the production of chopped semi-finished products from meat (beef, pork, mutton, chicken, duck) there was made a sampling of binary systems with different concentrates of algae and meat components.

The next stage was to develop combined minced meat using minced meat and plant concentrates according to the developed experimental methods.

Based on the pilot tests on determining the optimal formulas and technological modes of minced meat binary compositions combining algae and meat raw materials, the most important factors and the levels of their variations were determined and presented in Table 1.

Sensory analysis of the samples of minced meat combinations with algae was made in the laboratory of
Moscow State University of Technologies and Management named after K.G. Razumovsky. The samples of the products were encoded using random three-digit numbers. The results of the sample assessment of each tester were entered into the tasting list. The arithmetic mean of single parameters was calculated and fixed in the tasting lists (Table 2). On the basis of general assessment of the values of complex and single parameters there was drawn a conclusion about the product quality.

Table 3 shows the planning matrix of three stage experiment and the results of organoleptic assessment of the following binary compositions:

$$
\begin{aligned}
& -y 1-\text { beef }+ \text { algae; }-y 2-\text { pork }+ \text { algae } ;-y 3-\text { mutton }+ \\
& \text { algae; }-y 4-\text { chicken }+ \text { algae } ;-y 5-\text { duck }+ \text { algae }
\end{aligned}
$$

On the basis of the obtained results the regression analysis of dependences $\mathrm{y}_{\mathrm{i}}=\mathrm{f}\left(\mathrm{x}_{1}, \mathrm{x}_{2}, \mathrm{x}_{3}\right)$ was made and the mathematical models of organoleptic assessment of minced binary compositions was set in relation to the amount of protein product (algae), moisture content in the minced binary compositions and duration of their mincing.

Table 1. Factors and levels of variation

\begin{tabular}{|c|c|c|c|}
\hline \multirow{2}{*}{ Indicator } & \multicolumn{3}{|c|}{ Factors } \\
\cline { 2 - 4 } & $\begin{array}{c}\text { Amount of } \\
\text { algae }(\mathrm{C}), \\
\%\end{array}$ & $\begin{array}{c}\text { Moisture } \\
\text { content } \\
(\mathrm{W}), \%\end{array}$ & $\begin{array}{c}\text { Duration } \\
\text { of mincing } \\
(\mathrm{T}), \mathrm{c}\end{array}$ \\
\cline { 2 - 4 } & $\mathrm{X} 1$ & $\mathrm{X} 2$ & $\mathrm{X} 3$ \\
\hline $\begin{array}{c}\text { Interval of } \\
\text { variation }\end{array}$ & 20 & 20 & 120 \\
\hline Upper level (+) & 50 & 60 & 600 \\
\hline Basic level (0) & 30 & 40 & 480 \\
\hline Lower level (-) & 10 & 20 & 360 \\
\hline
\end{tabular}

Table 2. Organoleptic characteristics of minced combinations based on meat and algae

\begin{tabular}{|c|c|c|c|c|c|}
\hline $\begin{array}{c}\text { Minced } \\
\text { combination }\end{array}$ & $\begin{array}{c}\text { Amount } \\
\text { of algae }\end{array}$ & Form & Taste & Colour & Smell \\
\hline \multirow{4}{*}{ Beef } & 10 & 4.6 & 4.7 & 4.5 & 4.4 \\
\cline { 2 - 6 } & 30 & 4.8 & 5.0 & 4.9 & 4.8 \\
\cline { 2 - 6 } & 50 & 4.6 & 4.9 & 4.8 & 4.7 \\
\hline \multirow{4}{*}{ Pork } & 10 & 4.5 & 4.7 & 4.5 & 4.6 \\
\cline { 2 - 6 } & 30 & 4.7 & 4.8 & 4.6 & 4.7 \\
\cline { 2 - 6 } Mutton & 50 & 4.6 & 4.7 & 4.6 & 4.6 \\
\cline { 2 - 6 } & 10 & 4.7 & 4.6 & 4.5 & 4.4 \\
\cline { 2 - 6 } & 30 & 4.8 & 4.9 & 4.9 & 4.8 \\
\hline Chicken & 10 & 4.7 & 4.8 & 4.7 & 4.6 \\
\cline { 2 - 6 } & 30 & 4.8 & 5.0 & 4.9 & 4.8 \\
\cline { 2 - 6 } & 50 & 4.7 & 4.9 & 4.8 & 4.7 \\
\hline \multirow{4}{*}{ Duck } & 10 & 4.7 & 4.8 & 4.9 & 4.7 \\
\cline { 2 - 6 } & 30 & 4.8 & 4.9 & 5.0 & 4.9 \\
\cline { 2 - 6 } & 50 & 4.7 & 4.8 & 4.9 & 4.8 \\
\hline
\end{tabular}


Table 3. Planning matrix and results of the experiment

\begin{tabular}{|c|c|c|c|c|c|c|c|c|}
\hline \multirow{2}{*}{ № } & \multirow{2}{*}{$\mathrm{X} 1$} & \multirow{2}{*}{$\mathrm{X} 2$} & \multirow{2}{*}{$\mathrm{X} 3$} & \multicolumn{5}{|c|}{ General organoleptic assessment, grades } \\
\hline & & & & Y1 & Y2 & Y3 & Y4 & Y5 \\
\hline 1 & - & - & - & 26.1 & 27.2 & 26.0 & 25.5 & 27.0 \\
\hline 2 & + & - & - & 27.0 & 27.8 & 28.0 & 26.5 & 26.0 \\
\hline 3 & - & + & - & 24.5 & 24.0 & 24.0 & 24.0 & 24.0 \\
\hline 4 & + & + & + & 26.0 & 27.5 & 26.5 & 26.5 & 27.5 \\
\hline 5 & - & - & - & 26.3 & 28.0 & 26.3 & 24.5 & 24.5 \\
\hline 6 & + & - & + & 28.5 & 27.5 & 27.8 & 27.0 & 29.5 \\
\hline 7 & - & + & + & 26.0 & 26.0 & 27.4 & 25.0 & 25.5 \\
\hline 8 & + & + & - & 25.5 & 26.0 & 24.0 & 25.0 & 24.0 \\
\hline 9 & -1.215 & 0 & 0 & 25.7 & 26.5 & 24.5 & 27.0 & 25.5 \\
\hline 10 & 1.215 & 0 & 0 & 27.0 & 28.3 & 27.4 & 27.0 & 27.4 \\
\hline 11 & 0 & -1.215 & 0 & 27.0 & 28.0 & 27.9 & 29.3 & 28.0 \\
\hline 12 & 0 & 1.215 & 0 & 26.6 & 27.1 & 27.0 & 28.0 & 25.8 \\
\hline 13 & 0 & & -1.215 & 26.5 & 27.2 & 27.3 & 27.0 & 27.0 \\
\hline 14 & 0 & 0 & 1.215 & 29.5 & 29.1 & 28.8 & 28.0 & 28.0 \\
\hline 15 & 0 & 0 & 0 & 29.3 & 27.8 & 29.0 & 29.0 & 29.1 \\
\hline
\end{tabular}

The encoded mathematical models of organoleptic parameters of minced binary compositions are presented as the following equations

$$
Y_{1}=28,372+0,519 X_{1}-0,583 X_{2}-0,634 X_{3}-1,252 X_{1}^{2}
$$
$-0,947 X_{2}^{2}$

$$
Y_{2}=28.133+0.528 X_{1}-0,739 X_{2}+0,43 X_{3}+
$$
$0,425 X_{1} X_{2}+0,575 X_{2} X_{3}-0,69 X_{1}^{2}-0.588 X_{2}^{2}$

$Y_{3}=28.34+0,559 X_{2}-0.666 X_{2}+0,659 X_{3}-$ $0.555 X_{3} X_{2}+0,8 X_{2} X_{3}-1,567 X_{12}-0,551 X_{22}$

$Y_{4}=28.043-0,759 X_{1}+0,792 X_{2}+1,115 X_{3}+$ $0,375 X_{2} X_{3}-1,168 X_{12}-0,862 X_{22}-0,456 X_{32}$.

The modified mathematical models of organoleptic parameters of minced binary compositions are presented as follows:
$N_{l}=19.619+0,2137 \mathrm{C}+0,1602 \mathrm{~W}+0,0053 T-$ $0,0031 C_{2}-0.0024 W_{2}$

$N_{2}=29.07+0,0874 C-0,0662 W-0.006 T+$ $0,0011 C W+0.0002 W T-0.0017 C_{2}-0.0014 W_{2}$

$N_{3}=25.218+0.318 \mathrm{C}-0.048 \mathrm{~W}-0.0078 \mathrm{~T}-$ $0.0014 C W+0.0003 W T-0.0039 C_{2}-0.0014 W_{2}$

$N_{4}=29.59+0.2968 C-0.1565 C_{2}+0.1011 T-$ $0.0045 C_{2}+0.0017 W_{2}-0.0001 T_{2}$

$N_{5}=13.263+0.1382 C+0.1330 \mathrm{~W}+0.0350 T+$ $0.0002 C T-0.0029 C_{2}-0.0022 W_{2}-0.00003 T_{2}$

(9)

Using the methods of mathematical modeling the regression analysis of the mathematical modules $\mathrm{Y}_{1}-\mathrm{Y}_{5}=\mathrm{f}$ $\left(\mathrm{X}_{1} ; \mathrm{X}_{2} ; \mathrm{X}_{3}\right)$ is made.

Table 4 shows the results of the regression analysis

\begin{tabular}{|c|c|c|c|c|c|c|}
\hline \multicolumn{2}{|c|}{ Criteria } & Y1 & Y2 & Y3 & Y4 & Y5 \\
\hline \multicolumn{2}{|l|}{$\alpha 0$} & 28.372 & 28.1330 & 28.340 & 29.490 & 28.403 \\
\hline \multicolumn{2}{|l|}{$\alpha 1$} & 0.519 & 0.5280 & 0.559 & 0.5480 & 0.7590 \\
\hline \multicolumn{2}{|l|}{$\alpha 2$} & -0.583 & -0.7390 & -0.66 & -0.4180 & -0.7920 \\
\hline \multicolumn{2}{|l|}{$\alpha 3$} & 0.634 & 0.430 & 0.659 & 0.4760 & 1.1150 \\
\hline \multicolumn{2}{|l|}{$\alpha 12$} & 0.0000 & 0.425 & -0.550 & 0.0000 & 0.0000 \\
\hline \multicolumn{2}{|l|}{$\alpha 13$} & 0.0000 & 0.0000 & 0.0000 & 0.0000 & 0.375 \\
\hline \multicolumn{2}{|l|}{$\alpha 23$} & 0.0000 & 0.575 & 0.800 & 0.0000 & 0.0000 \\
\hline \multicolumn{2}{|l|}{$\alpha 11$} & -1.252 & -0.690 & -1.567 & -1.7960 & -1.168 \\
\hline \multicolumn{2}{|l|}{$\alpha 22$} & -0.947 & -0.588 & -0.551 & 0.6780 & -0.8630 \\
\hline \multicolumn{2}{|l|}{$\alpha 33$} & 0.0000 & 0.0000 & 0.0000 & -1.457 & -0.456 \\
\hline \multirow{2}{*}{ Approximation } & FR & 6.4903 & 8.7079 & 10.103 & 18.126 & 9.0814 \\
\hline & FT & 5.960 & 4.770 & 4.770 & 8.790 & 9.790 \\
\hline
\end{tabular}

Table 4. The Results Of The Regression Analysis Of The Mathematical Models 
Thus, the results of organoleptic assessment received from the check-lists of the paired comparison showed only the difference in the certain organoleptic parameters of the quality of the minced binary combinations made from meat with various amount of algae. Their organoleptic assessment by means of five-point grading scale allowed not only to assess the level of the quality of minced binary combinations, but to get the mathematical models that help determine the optimal values of the factor and $\mathrm{C}, \mathrm{W}, \mathrm{T}$ (concentration of the components, moisture content and duration of mincing).

This research allows making a conclusion that the optimal values of the factors are:

- algae content in minced compositions - 30\%

- moisture content - 50-60\%

- duration of mincing - $6 \mathrm{~min}$.

The results of organoleptic assessment of the quality of minced binary compositions made in accordance with the optimal parameters C, W, T (Figure 1) indicate on the different level of the quality of minced compositions form different meat raw materials. It is shown that the range of fluctuations in the assessment of their quality is from 92.6 to $97.6 \%$.

The comparative organoleptic assessment showed the different level of the quality of minced binary compositions, depending on the ration of algae: meat is improving by all the main parameters in the following order: y1, y3, y4, y5, y2.

The best results are obtained in the combination beef + algae and duck + algae with the concentration $30 \%$ of algae.

Further, these data are used in the development of the formulas of the functional chopped and minced meat products.

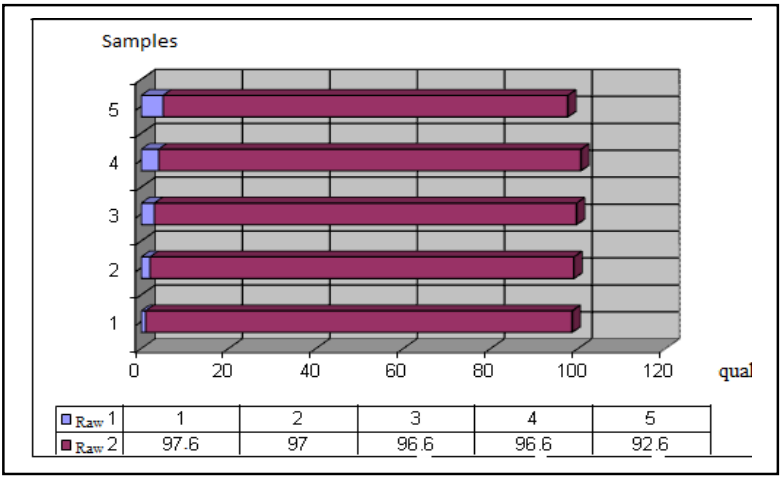

Fig. 1. Organoleptic assessment of minced binary compositions 1. beef + algae; 2 . duck + algae; 3 . mutton + algae; 4 . chicken + algae; 5 . pork + algae

\section{Conclusion}

The concentrations $10 \%$ and $30 \%$ of algae as a component of meat and plant system of chopped semi-finished products had no specific flavour and aroma during the tasting assessment. The increase in the content of the plant component up to $50 \%$ contributed to the increase in the product output and enhanced algae flavour.

Therefore, it is advisable to study the chopped semifinished products with $10-30 \%$ algae content

\section{References}

1. K.N. Nitsievskaya, O.K. Motovipov, and O.S Grushina, Vestnik of KrasGAU, 208-212, (2011)

2. S.V. Esaulov, Development of chopped meat semifinished products with calcium animal protein compositions (2009)

3. T.V. Pershakova, T.V. Pershakova, A.T. Vasyukova, T.S. ZHilina, T.V. YAkovleva, V.F. Puchkova, and I.A. Fedorkina, Food Industry, 319, 36-37, (2011)

4. A.T. Vasyukova, I.A. Leonov, V.L. Zaharov, and M.V. Vasyukov, Development and explanation of the technology of grilled semi-finished products (Lambert, Academic Publishing, Saarbrucken, Germany, 2016)

5. V.B. Chmykhalova, Vestnik of Kamchatka State Technical University, 66-78, (2012)

6. K.L. Konovalov, M.T. SHulbaeva, and O.N. Musina, Food Industry, 8, 10-12, (2008)

7. G. Levis, N. Stanley, and G. Guist, Algae and Human Affairs, 206-232, (1988)

8. S.T. Moe, K.I. Draget, and G. Skjak-Brake, Food Polysaccharides and their applications, 245-286, (1995)

9. A.T. Vasyukova and M.V. Vasyukov, International Journal of Innovative Studies in Sciences and Engineering Technology, 3, 15-18, (2017).

10. A. Moshkin, A.T. Vasyukova, and M. Novozhilov, Znanstvena misel journal, 1, 46-52, (2019)

11. B. Kabulov, S. Kassymov, Z. Moldabayeva, M. Rebezov, O. Zinina, Y. Chernyshenko, F. Arduvanova, G. Peshcherov, S. Makarov, and A. Vasyukova, Eurasia J Biosci, 14, 213-218, (2020)

12. M.A. Kolodko, L.A. Zabodalova, and V.N. Krasil'nikov, Low temperature food technologies in the XXIst century, 247-253, (2007)

13. A.T. Vasyukova, V.F. Puchkova, T.S. ZHilina, N.A. Kuharenkova, and I.G. Utarova, Educational medium today and tomorrow, pp. 168-171, (2016)

14. A.T. Vasyukova, A.V. Podkorytova, L.H. Vafina, N.I. Myachikova, and L.V. Dracheva, Fat and Oil Industry, 3, 22-24, (2015)

15. L.Kh. Vaphina, Substantiation of the complex processing of algae (Phaeophyta) while producing functional food products, (2010)

16. D.G. Oakenfuul, CSIRO Food Research Quart, 44, 49-50, (1984)

17. A.A. Slavyanskiy, M.B. Moyseak, V.M. Didenko, and L.S. Petova, Use of food SAW for intensification of technological processes of sugary sector, (2005)

18. E.V. Semenov, A.A. Slavyanskiy, and V.A. Karamzin, Chemical and Oil Machine building, 11, 7-10, (2014)

19. E. Kalakovskiy, Technology of minced fish meat. (Agropromizdat, Moskow, 1991) 
20. S.S. Khruschev, A.M. Abaturova, A.N. D'yakonova, D.M. Ustinin, D.V. Zlenko, V.A. Fedorov, I.B.

Kovalenko, G.YU. Riznichenko, and A.B. Rubin,

Informatics and Modelling, 5, 47-64, (2013)
21. M.A. Nikitina, A.N. Zaharov, V.V. Nasonova, and A.B. Lisicyn, Theory and Practice of Meat Processing, 3, 63-77, (2017) 